\title{
The Strategy of Cultivating Intercultural Communication Ability in College English Education
}

\author{
Teng Ma \\ Northwestern Polytechnical University Mingde College \\ lidongnew@sina.com
}

Keywords: College English; Quality education; Intercultural

\begin{abstract}
At present, with the deepening and reform of the education and teaching system, we should pay attention to the cultivation of university intercultural communication ability in the process of teaching college English courses. At the same time, in the process of cultivating students, we gradually pay attention to cultural exchanges and cultural transmission, and effectively improve students' learning efficiency and learning effects through cultural teaching. This paper mainly studies and analyzes the intercultural communication competence in college English teaching.
\end{abstract}

\section{Introduction}

At present, intercultural teaching ability mainly refers to the effective combination of native language culture and non-native language culture in the actual course teaching process, through the integration of teaching, different cultural contents can be fully combined, including different cultures, customs and social backgrounds, etc. Through intercultural teaching, each student's learning ability in the process of English learning can be effectively improved. Intercultural communication competence is a kind of teaching method which is gradually popularized and emerging in order to cultivate students' communicative competence. Through moral quality, ideological understanding, language ability and cultural knowledge to effectively realize the comprehensive development of students and enhance students' intercultural communication. On the one hand, college English is to effectively broaden the students' ability and ability to learn language. It also enables students to better understand the cultural background of English and the differences in different world cultures, and improve the overall quality and ability of students. Therefore, in the process of teaching college courses, we should pay attention to intercultural teaching work and content, on the one hand, improve students' English learning effect, on the one hand to improve students' English learning, but also students and other positive character traits.

\section{Significance of the Cultivation of Intercultural Communication Ability in College English Quality Education}

In the current process of cross-cultural English teaching, the cultivation of students' intercultural communication ability mainly refers to the cultivation of students' language quality ability and quality in the process of English teaching.

\section{Improve Interest}

In the process of teaching English as a foreign language, the intercultural teaching mode and content are all to make students pay more attention to English, enhance students' interest in learning English, through Intercultural teaching methods, students' learning interest and enthusiasm can be effectively improved, and students' learning sense can be enhanced. In many cases, college English courses are simply teaching words, reading sentences, etc. The actual teaching results are often unsatisfactory. In the process of intercultural communication competence training, we can adopt an effective teaching method, combining it with the language background will combine cross-cultural teaching content into words and sentences, and make the customs and habits of different regions and religious beliefs in different regions provide supplementary explanations, then students' enthusiasm for learning and interest in learning can be significantly improved, which is of great 
significance to the future development and progress of students.

Improve students' language communication ability

The current students' communicative competence is an important manifestation of language learning, students' language communicative competence usually shows their mastery degree and effect of course learning. At present, college English quality education often attaches importance to the cultivation of cultural communication ability, which is conducive to improving students' overall communication ability.

During the process of teaching college English courses, as teachers, we should attach importance to the students' communicative competence as the first training work, and strengthen the introduction of culture, Meanwhile, we should effectively teach students' cultural differences between China and the west, systematically understand from multiple perspectives and aspects, and better implement intercultural teaching. The different aspects of Chinese and Western society have great differences in ideology, and there are also significant differences in culture and so on, therefore, in the course of teaching, through the teaching of culture and the cultivation of intercultural communication ability, students can have more cognitive effects on language and improve their future language ability and literacy.

\section{Training method of College English Intercultural Communication Ability}

In the course of college English teaching, we should comprehensively teach the language under different cultural backgrounds, and form a kind of educational teaching mode that can improve students' intercultural communication ability, in the process of quality education, we will form a A good world view, outlook on life and values.

\section{Increase the proportion of intercultural teaching content}

In the current process of teaching English for teachers, appropriate teaching of language and cultural knowledge should be carried out, First of all, students can fully understand the differences between Chinese and Western cultures. In the actual teaching process, teachers can introduce certain Western cultural backgrounds, and can also carry out the dissemination of cultural knowledge through American dramas and English dramas, through the American drama teaching method, on the one hand, students can better understand the relevant development points of the current Western culture, and at the same time, they can improve the students' oral communication ability to a certain extent, it is the communicative ability of Westerners in a real situation and environment, which has an important effect on the development of students.

At the same time, teachers should appropriately expand the language professional knowledge and the content of cultural information according to the content and proportion of the textbooks, and fully integrate the cultural contents of countries such as the United Kingdom and the United States, students should understand the difference of the communicative competence in different cultural backgrounds in the process of learning English. Cultural background knowledge mainly includes geography, history, religion, humanities and other aspects, in the process of learning culture, students should think and imagine the problems according to the cultural thinking of foreigners. At the same time, they should study and think in all aspects and in all directions, In terms of textbook compiling rules, it can be carried out in a step-by-step manner, from simple to difficult, the teaching of oral English communication skills is gradually carried out, and the knowledge of English culture background is gradually penetrated to realize the all-round improvement of students.

\section{Strengthen teachers' guidance on intercultural content}

In addition to doing a corresponding proportion of cross-cultural teaching in the textbooks, we also should effectively play the guiding role of teachers in the actual teaching process, in order to achieve intercultural communication skills, on the one hand, students should continue to learn and improve themselves, while teachers also need to make the appropriate guidance, guide students to learn and understand western culture and knowledge, selective guidance work can often effectively reduce students' detours in the actual course of learning, innovative teaching methods can also be used to properly promote and spread Chinese and Western cultures, combine the organization of 
Western cultural content with language learning, students can achieve the combination of culture and content in real language situations.

Finally, teachers should break the conventional teacher-centered teaching ways and teaching methods in the actual teaching process, under the impetus of the new model, teachers should guide as an ancillary role in the teaching process, give students more time to think and imagine, in the learning process of the subject,they can draw inferences about other cases from one instance

and master the contents of cross-cultural knowledge, guide students to use English to express their thoughts, exchange emotions, etc., so that students can participate in cultural learning and communication, so that students' intercultural communication ability is continuously improved.

\section{Use scientific methods to teach intercultural content}

In the actual teaching process, on the one hand, college English quality education is to acquire and master knowledge, and on the other hand, it also has a certain understanding of external culture, world view and values, these cultures often come from different regions and channels in the actual learning process, scientific methods and effective teaching materials should be used for comprehensive teaching. In the actual teaching process, teachers should pay attention to the scientific principle and ideological principle, so that students have a comprehensive understanding of the western mainstream culture, and actively introduce the content of western culture. In the teaching process, a series of different ideologies, contents, etc. are often involved, learning and teaching should be carried out critically in the process of teaching, taking the essence and discard the dregs, guiding college students to form a correct and scientific world outlook and values and cultivate a good intercultural awareness.

\section{Make full use of multimedia and other information means}

In the process of teaching college English, the computerized information teaching method has been gradually promoted, through computer and multimedia, the teaching effect can be effectively improved, and more teaching resources can be projected, let the students master more teaching content in the process of learning in just one hour, and have a more comprehensive understanding and knowledge of western culture. Multimedia technology can visualize a series of abstract concepts, and can also output contextual dialogues in books through audio, to a certain extent, it effectively improves the learning effect of students, that students can get closer to the teaching connotation of the course.

In the process of making PPT, teachers can also put some TV dramas, movies and other video materials from the West on the projector, so that students feel the foreign culture and customs in an immersive way, provide a variety of materials and forms of learning opportunities for students to practice the language and intercultural opportunities, effectively develop students' quality cultural ability and intercultural communication skills.

\section{Summary}

Based on the above, the author mainly analyzes and explores the intercultural communication ability and related teaching methods in the current college English education. The cultivation of intercultural communication competence in college English quality education is of great significance and effect for the future development of students. A country or a nation often has its own ideology and cultural thoughts, in the process of learning foreign thoughts and cultures, we need to pay attention to understanding the ideological culture and ideology of foreign people. Only in this way can we improve the ability of oral communication, understand the culture of a country from the inside to outside, and constantly improve Students' intercultural communication skills.

\section{References}

[1]Wu Siying. Research on the Cultivation of Intercultural Communication Ability of Non-English Majors in College English Teaching[J]. Overseas English, 2018(16): 103-104. 
[2]Liu Zhenyu, Chen Yao. Research on the Development and Reform of College English EGP+ESP Paradigm from the Perspective of Intercultural Communication[J].Economist, 2018(08):226+228.

[3]Niu Yanqing. Research on College English Cross-Cultural Teaching under Economic Globalization—Comment on "College English Intercultural Teaching Research under the Background of Globalization"[J].News \& Writing,2018(06):116.

[4]Jia Weili, Xu Huiqun. The Teaching Mode of College English Intercultural Communication under the "Belt and Road" Strategy__ Taking the Long Nan Teachers College as an Example[J]. Inner Mongolia Electric University Journal, 2018(03): 72-74.

[5]Xie Yaojing. The Application of "Output-Oriented Method" in Morning Exercises of English Communicative Competence_-Taking Guang xi Foreign Language College as an Example[J]. Comparative Study on Cultural Innovation, 2018, 2(13): 69-72.

[6]Gu Yalan. The Application of Cultural Two-way Teaching Model in College English Teaching__ Taking Luoyang Institute of Technology as an Example[J]. Journal of Kaifeng College of Education, 2018, 38(04): 64-65.

[7] Peng Bingzhuan. The Cultivation of College English Intercultural Communication Ability and the Reconstruction of Evaluation System from the Perspective of Language Subjectivity[J]. Heilongjiang Education (Theory and Practice), 2018(03): 57-58.

[8] Ma Xiaoli, Zhang Tongjun. On the Cultivation of Intercultural Communication Ability in College English Follow-up Teaching___ Taking Lanzhou University of Arts and Science as an Example[J].Journal of Changchun Institute of Technology(Social Science Edition),2018,19(01):51- 54. 